Article

\title{
Release of Extracellular Polymeric Substance and Disintegration of Anaerobic Granular Sludge under Reduced Sulfur Compounds-Rich Conditions
}

\section{Takuro Kobayashi ${ }^{1, *}$, Kai-Qin Xu ${ }^{1,2}$ and Haruyuki Chiku ${ }^{3}$}

1 Center for Material Cycles and Waste Management Research, National Institute for Environmental Studies, 16-2 Onogawa, Tsukuba, Ibaraki 305-8506, Japan; E-Mail: joexu@nies.go.jp

2 School of Environmental Science and Engineering, Shanghai Jiao Tong University, 800 Dongchuan road, Minghang district, Shanghai 200240, China

3 Research and Development Center, Sumitomo Heavy Industries Environment Co., Ltd., Yokosuka, Kanagawa 237-8555, Japan; E-Mail: hry_chiku@shi.co.jp

* Author to whom correspondence should be addressed; E-Mail: kobayashi.takuro@nies.go.jp; Tel.: +81-29-850-2400; Fax: +81-29-850-2560.

Academic Editor: Thomas E. Amidon

Received: 24 June 2015 / Accepted: 24 July 2015 / Published: 31 July 2015

\begin{abstract}
The effect of reduced form of sulfur compounds on granular sludge was investigated. Significant release of extracellular polymeric substance (EPS) from the granular sludge occurred in the presence of sulfide and methanethiol according to various concentrations. Granular sludge also showed a rapid increase in turbidity and decrease in diameter in accordance with sulfide concentration during the long-term shaking, suggesting that the strength of the granules was reduced with high-concentration sulfide. A continuous experiment of up-flow anaerobic sludge blanket reactors with different concentrations of sulfide (10, 200, $500 \mathrm{mg}-\mathrm{S} / \mathrm{L})$ influence demonstrated that the reactor fed with higher concentration of sulfide allowed more washout of small particle-suspended solid (SS) content and soluble carbohydrate and protein, which were considered as EPS released from biofilm. Finally, the presence of sulfide negatively affected methane production, chemical oxygen demand removal and sludge retention in operational performance.
\end{abstract}

Keywords: granular sludge; reduced sulfur compounds; extracellular polymeric substance (EPS) 


\section{Introduction}

Granular sludge-based system including up-flow anaerobic sludge blanket (UASB) and expanded granular sludge bed (EGSB) is commonly employed for biological treatment of industrial wastewater around the world [1,2]. The high-rate organic matter removal of the system depends on good settling biomass inside the reactor, allowing long solids retention time (SRT) and process stability. Granule is a kind of concentrated multilayered biofilm including different microbial trophic groups: acidogenic bacteria, syntrophic acetogenic bacteria and methanogenic archaea. These microbial groups produce EPS around the cells, which help the microorganisms attach each other and create large cell aggregations [3].

The granulation and the stability of the granules are commonly considered to be strongly affected by various environmental and operational conditions [4]. The critical factors affecting granulation are nutrient balance, $\mathrm{pH}[5,6]$, temperature [7], wastewater composition [8,9], EPS production and surface charge $[10,11]$. Since there is wide variety of wastewater providing different environmental and operational conditions in reactors due to different industries, it has become clear that some kinds of wastewaters are difficult to form granules and retain biomass successfully. Some of the factors responsible for this issue have been studied recently. Very poor granulation was observed in the UASB reactor treating fat, oil and grease (FOG)-rich substrate [12,13]. Chou and Huang [14] observed that smaller granules were formed in the phenol-fed UASB reactor than in the sucrose-fed reactor. Borzacconi et al. [15] demonstrated that formation of filamentous granule with poor settling velocity caused washout of the biomass in a full-scale UASB reactor treating malting plant effluent. Ismail et al. [16] reported that granules developed under higher salinity condition contained lower EPS concentration and showed lower strength. In practical applications, principal factors and underlying mechanisms of inhibiting granulation are still not clear.

Sulfur compounds are common contaminants in industrial wastewaters. A lot of researchers have investigated sulfate-rich wastewater treatment with UASB reactors and pointed out negative aspects of the presence of sulfate such as decrease in methane yield due to competition between methanogen and sulfate-reducing bacteria (SRB) and inhibition by sulfide produced by SRB [17-19]. Although most researchers have discussed the oxidized forms of sulfur compounds (sulfate, sulfite, thiosulfate) in input stream of industrial wastewater, however, influent of UASB and EGSB reactors also sometimes contains only reduced sulfur compounds including sulfide, methanethiol, dimethyl sulfide (DMS) and dimethyl disulfide (DMDS) instead of the oxidized ones. For example, wastewater produced from textile, leather, oil refining, chemical, pulp and paper industries contain reduced forms of sulfur compounds such as sulfide, DMS, methanethiol, dithionate, polythionate and thiocyanate. As such, it is still unknown how very high concentrations of these reduced sulfur compounds affect granular sludge and operation performance of UASB reactor. The reduced sulfur compounds (e.g., sulfide and methanthiol) are known to easily form insoluble salts with multivalent metal ions $\left(\mathrm{Fe}^{2+}, \mathrm{Zn}^{2+}, \mathrm{Co}^{2+}\right.$, etc.), which play important roles in enzymatic reactions and cation-EPS-cell interaction by forming complex matrix in the biofilm [20]. It has been demonstrated that $\mathrm{Ca}^{2+}, \mathrm{Fe}^{2+}, \mathrm{Al}^{3+}$ and $\mathrm{Mg}^{2+}$ slightly enhance the granulation [21-24]. A significant precipitation of those metal cations as salts by adding the sulfur compounds reduces the multivalent cation concentrations in liquid phase compared to monovalent cation ones, and seems to cause decrease in the cations responsible for the complex matrix in granules by ion-exchange between the multivalent cations and monovalent cations such as $\mathrm{Na}^{+}$, which reduced 
EPS content in the granules [16]. This can weaken structure in the granules and lead to reduced granule sizes. Actually, it was observed that the granular sludge appeared to change during the long-term exposure to 200-500 mg-S/L reduced sulfur compounds in a full-scale mesophilic EGSB reactor treating methanol-based wastewater. The concentration is very high level since Speece [25] suggested $100 \mathrm{mg} / \mathrm{L}$ to $150 \mathrm{mg} / \mathrm{L}$ sulfide lead to severe inhibition of methanogenesis. Small granules have relatively low settling velocity and therefore they are easily washed out of a reactor. Decrease in sludge concentration due to wash-out of granules is one of the major problem affecting reactor performance in anaerobic wastewater treatment. In the present study, the effect of exposure to high concentration reduced sulfur compounds on the granular sludge using the granules taken from the full-scale reactor was explored in batch experiments and a continuous experiment of UASB reactors fed with artificial wastewater imitating the composition of influent wastewater into the full-scale EGSB reactor. This study focused on: (1) EPS release; (2) change of granule size distribution; and (3) operation performance and sludge retention in UASB reactors.

\section{Materials and Methods}

\subsection{Experimental Setup}

\subsubsection{Extracellular Polymeric Substance (EPS)-Elution Experiment}

Batch tests of EPS-elution were performed using plastic bottles with a volume of $50 \mathrm{~mL}$. The seed granular sludge was taken from a full-scale EGSB reactor treating wastewater from chemical industry. Four reduced forms of sulfur compounds $\left(\mathrm{Na}_{2} \mathrm{~S} \cdot 9 \mathrm{H}_{2} \mathrm{O}\right.$, methanethiol, DMS and DMDS) were mainly contaminated in the influent of the EGSB reactor. Each sulfur species and $0.1 \mathrm{~g}$-SS granules were added into the bottles with $20 \mathrm{~mL}$ phosphate-buffered saline (PBS), respectively. The concentration ranges of sulfur compounds were $0 \mathrm{mg}-\mathrm{S} / \mathrm{L}, 100 \mathrm{mg}-\mathrm{S} / \mathrm{L}, 300 \mathrm{mg}-\mathrm{S} / \mathrm{L}, 500 \mathrm{mg}-\mathrm{S} / \mathrm{L}$ and $700 \mathrm{mg}-\mathrm{S} / \mathrm{L}$. Since DMS and DMDS are difficult to dissolve in water, these were added after being dissolved in $0.3 \mathrm{~mL}$ of ethanol. The final composition of PBS was: $7 \mathrm{mM} \mathrm{Na} 2 \mathrm{HPO}_{4} \cdot 7 \mathrm{H}_{2} \mathrm{O}, 3 \mathrm{mM} \mathrm{NaH} \mathrm{PO}_{4} \cdot \mathrm{H}_{2} \mathrm{O}$, $9 \mathrm{mM} \mathrm{NaCl}$, and $1 \mathrm{mM} \mathrm{KCl}$. After adjusting $\mathrm{pH}$ to 7.0 using $\mathrm{HCl}$, water was added to make $30 \mathrm{~mL}$. Then, the headspace of the bottles was flushed with nitrogen gas, and sealed with screw caps. The bottles were anaerobically shaken on rotary shakers (Multi shaker MMS, EYELA, Tokyo, Japan) at a shaking speed of $120 \mathrm{rpm}$ for $3 \mathrm{~h}$ in the laboratory incubator $\left(35^{\circ} \mathrm{C}\right)$, The supernatant was obtained as EPS after the centrifugation (12,000 g, $15 \mathrm{~min}$ ) and filtration by a membrane filter (0.45 $\mu \mathrm{m}$ pore size). The residual granular sludge was collected via filtration using a sieve ( $0.5 \mathrm{~mm}$ pore size) and washed with water to remove FeS. Then, the absorbed $\mathrm{Fe}^{2+}$ content in the granules was measured. As a reference experiment, EPS release with cation exchange resin (CER) was conducted. The mixture of 6 g (60 g/g-SS) Dowex Marathon C sodium form (Sigma-Aldrich, St. Louis, MO, USA), 0.1 g-SS granules and $30 \mathrm{~mL}$ PBS ( $4 \mathrm{mM} \mathrm{NaH} \mathrm{PO}_{4}, 9 \mathrm{mM} \mathrm{NaCl}, 1 \mathrm{mM} \mathrm{KCl}, \mathrm{pH} 7.0$ ) were added into the beaker. The mixture was stirred at a speed of $600 \mathrm{rpm}$ for $2 \mathrm{~h}$. After centrifugation (12,000 g, $15 \mathrm{~min}$ ), supernatant was obtained via filtration using a membrane filer $(0.45 \mu \mathrm{m}$ pore size $)$ as EPS. All the experiments were repeated three times. 


\subsubsection{Granule-Dispersion Experiment}

To understand changes in granule size distribution in the presence of sulfide, EPS-elution tests were conducted using larger reactors to take samples every $2 \mathrm{~h}$. Reactors were three glass bottles with sampling ports and screw caps. The working volume of each bottle was $500 \mathrm{~mL}$. The PBS, $\mathrm{Na}_{2} \mathrm{~S} \cdot 9 \mathrm{H}_{2} \mathrm{O}$ and $1.2 \mathrm{~g}$-SS granules taken from the full-scale reactor were added to the glass bottles, respectively. The concentration range of sulfide was 0,200 and $500 \mathrm{mg}-\mathrm{S} / \mathrm{L}$. The final composition of PBS was: $7 \mathrm{mM} \mathrm{Na} 2 \mathrm{HPO}_{4} \cdot 7 \mathrm{H}_{2} \mathrm{O}, 3 \mathrm{mM} \mathrm{NaH} 2 \mathrm{PO}_{4} \cdot \mathrm{H}_{2} \mathrm{O}, 9 \mathrm{mM} \mathrm{NaCl}$, and $1 \mathrm{mM} \mathrm{KCl}$. After adjusting $\mathrm{pH}$ to 7.0 using $\mathrm{HCl}$, water was added to make $500 \mathrm{~mL}$. The headspace of the bottles was flushed with nitrogen gas, and sealed with screw caps. The bottles were shaken at a speed of $140 \mathrm{rpm}$ on a rotary shaker in the incubator $\left(35^{\circ} \mathrm{C}\right)$. Every two hours, a sample of the sludge in the bottles was taken with a glass syringe via the sampling ports. Although the experiments were finished after $24 \mathrm{~h}, 8 \mathrm{~h}$ was considered as enough duration because there was no significant difference in EPS release, turbidity and size distribution between the samples after $8 \mathrm{~h}$ and $24 \mathrm{~h}$.

\subsubsection{Continuous Operation of Up-Flow Anaerobic Sludge Blanket (UASB) Reactors}

In the continuous experiment, three UASB processes fed with different concentrations of $\mathrm{Na}_{2} \mathrm{~S} \cdot 9 \mathrm{H}_{2} \mathrm{O}$ were operated. The sulfide concentrations in the influent wastewater were 10 (control), 200 (run 1), 500 (run 2) mg-S/L because the concentration of sulfur compounds in the influent of the full-scale reactor varied from $200 \mathrm{mg}-\mathrm{S} / \mathrm{L}$ to $500 \mathrm{mg}-\mathrm{S} / \mathrm{L}$. The schematic diagram of the experiment system is shown in Figure 1. The system consists of a feed tank $\left(4^{\circ} \mathrm{C}\right)$, UASB reactor $\left(35^{\circ} \mathrm{C}\right)$, a gas counter, a feeding pump cool water circulator and hot water circulator. The UASB reactor consists of reaction zone and gas-liquid-solid phase separator. There are 8 sampling ports from the top to the bottom of the reactor (Ports 1-8), as shown in Figure 1. The working volume of reaction zone was $4 \mathrm{~L}$ with $8 \mathrm{~cm}$ in internal diameter and $80 \mathrm{~cm}$ in height. The temperature of the reaction zone was maintained at $35{ }^{\circ} \mathrm{C}$ by a water jacket connected to the hot water circulator. The seed granular sludge was obtained from the full-scale EGSB reactor. After removing small granules with a test sieve $(0.5 \mathrm{~mm}$ pore size), approximately $2.7 \mathrm{~L}$ seed granules were added to each reactor, respectively. The amount of biogas produced was measured with the gas counter $\mu$ flow (Bioprocess control, Lund, Sweden), which shows the value at the standard state $\left(0^{\circ} \mathrm{C}, 1 \mathrm{~atm}\right)$. Hydraulic retention time (HRT) was gradually shortened from 4 days, 2 days and 1.5 days to 1 day, and a long-term operation was performed at the HRT of 1 day. The substrate-feeding rate by a roller pump was increased according to shortening HRT. The chemical oxygen demand (COD) and trace metal concentrations of the influent wastewater were determined according to those of the methanol-based real wastewater. The compositions of the wastewater used were as follows (in $1 \mathrm{~L}$ ): $9500 \mathrm{mg}-\mathrm{COD}$ methanol, $500 \mathrm{mg}$-COD sucrose, $850 \mathrm{mg}$ $\mathrm{NH}_{4} \mathrm{Cl}, 250 \mathrm{mg} \mathrm{K} 2 \mathrm{HPO}_{4}, 100 \mathrm{KH}_{2} \mathrm{PO}_{4}, 2083 \mathrm{mg} \mathrm{NaHCO}$, $625 \mathrm{mg} \mathrm{FeCl} \cdot 4 \mathrm{H}_{2} \mathrm{O}, 263 \mathrm{mg} \mathrm{CaCl} 2 \mathrm{H}_{2} \mathrm{O}$,

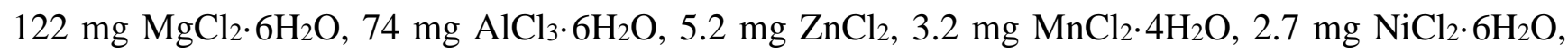
$1.4 \mathrm{mg} \mathrm{CoCl} \cdot 6 \mathrm{H}_{2} \mathrm{O}, 1.1 \mathrm{mg} \mathrm{CuCl} \cdot 2 \mathrm{H}_{2} \mathrm{O}, 0.5 \mathrm{NaMoO}_{4} \cdot 2 \mathrm{H}_{2} \mathrm{O}, 305 \mathrm{mg} \mathrm{Na}_{2} \mathrm{C}_{6} \mathrm{H}_{5} \mathrm{O}_{7} \cdot 2 \mathrm{H}_{2} \mathrm{O}$, and $75 \mathrm{mg}$ (control), $1500 \mathrm{mg}$ (run 1), or $3750 \mathrm{mg}$ (run 2) $\mathrm{Na}_{2} \mathrm{~S} \cdot 9 \mathrm{H}_{2} \mathrm{O}$. 


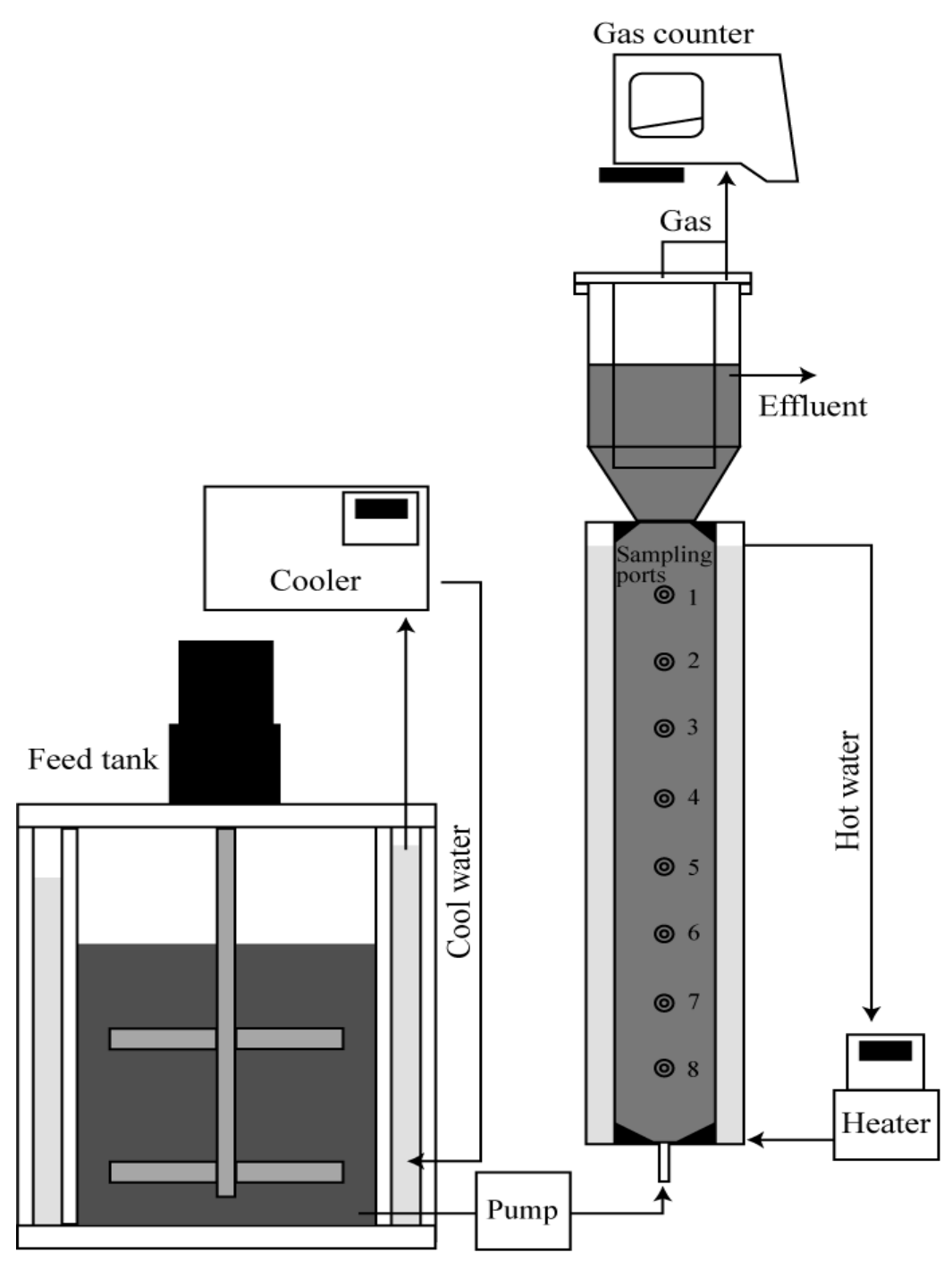

Figure 1. The schematic of the experimental apparatus.

\subsection{Methanogenic Activity Test}

The methanogenic activities of granular sludge taken from the UASB reactors were determined in batch anaerobic digestion tests using glass vials. The tests were run in triplicate. Substrate was methanol and sucrose (95:5 based on COD), having the same composition as influent wastewater. The initial COD concentration was $2000 \mathrm{mg} / \mathrm{L}$. The other nutrients were as follows (in $1 \mathrm{~L}$ ): $1.09 \mathrm{~g} \mathrm{~K}_{2} \mathrm{HPO}_{4}, 0.85 \mathrm{~g} \mathrm{KH}_{2} \mathrm{PO}_{4}, 3.0$ g $\mathrm{NaHCO}_{3}, 1.0 \mathrm{~g} \mathrm{MgCl}_{2} \cdot 6 \mathrm{H}_{2} \mathrm{O}, 0.375 \mathrm{~g} \mathrm{CaCl}_{2} \cdot 2 \mathrm{H}_{2} \mathrm{O}, 1.25 \mathrm{~g}$ $\mathrm{NH}_{4} \mathrm{Cl}, 2.18 \mathrm{~g} \mathrm{~K}_{2} \mathrm{HPO}_{4}, 1.7 \mathrm{~g} \mathrm{KH}_{2} \mathrm{PO}_{4}$, $2.5 \mathrm{~g} \mathrm{NaHCO}$, $0.5 \mathrm{~g}$ Cystein $\cdot \mathrm{HCl} \cdot \mathrm{H}_{2} \mathrm{O}, 2.0 \mathrm{mg} \mathrm{FeCl} \cdot 4 \mathrm{H}_{2} \mathrm{O}$,

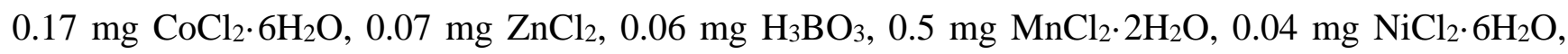
$0.027 \mathrm{mg} \mathrm{CuCl} 2 \cdot 2 \mathrm{H}_{2} \mathrm{O}, 0.025 \mathrm{mg} \mathrm{NaMoO} \cdot 2 \mathrm{H}_{2} \mathrm{O}$, and $0.5 \mathrm{~g} \mathrm{Na} 2 \cdot 9 \mathrm{H}_{2} \mathrm{O}$. During the continuous experiment, the sludge of each reactor was taken from the middle part of the reaction zone (sampling port 5), and about $2 \mathrm{~g}$ of wet granules including only granule-like biomass was transferred to a $120 \mathrm{~mL}$ glass vial. The $70 \mathrm{~mL}$ of nutrient solution was added to the vial and the headspace was flushed by nitrogen gas and sealed. The vials were shaken at a speed of $90 \mathrm{rpm}$ on the rotary shaker in the laboratory incubator $\left(35^{\circ} \mathrm{C}\right)$. The methanogenic activity was calculated as the rate of methane accumulation per gram SS versus time. 


\subsection{Analysis}

A supernatant for the measurement of soluble protein was prepared filtering through a membrane filter (0.45 $\mu \mathrm{m}$ pore-size) after a centrifugation (12,000 g, $15 \mathrm{~min}$ ). SS and volatile suspended solid (VSS) were measured according to examination method for wastewater [26]. Hydrogen sulfide concentration was measured using test tubes (4LL and 4H, GASTEC, Ayase-Shi, Japan). Total sulfide concentration was measured with test tubes $\left(201 \mathrm{H}\right.$, GASTEC). Concentration of $\mathrm{Fe}^{2+}$ ion was determined by phenanthroline spectrophotometry at $525 \mathrm{~nm}$ (HI96721, HANNA instruments, Woonsocket, RI, USA). Absorbed exchangeable $\mathrm{Fe}^{2+}$ ion was extracted five-times with $1 \mathrm{M}$ ammonium acetate from granule samples. Turbidity was determined using Turbidimeter 2100P (HACH, Loveland, CO, USA) according to the user's manual. The COD was measured with Digestion Solution for COD HR kit with $\mathrm{Cr}_{2} \mathrm{O}_{7}{ }^{2-}$ (HACH, Loveland, CO, USA). The composition of biogas produced was determined using a gas chromatograph GC-8A (Shimadzu, Kyoto, Japan) equipped with thermal conductivity detector (TCD) and a stainless steel column packed with Shincarbon ST (Shimadzu GLC, Tokyo, Japan). The pH was determined using a pH meter (TOA-DKK, Tokyo, Japan) equipped with a GST-5721C probe (TOA-DKK). The carbohydrate concentration was measured according to the phenol-sulfuric acid method, using glucose as the standard. Protein content was measured according to Bradford protein assay using bovine serum albumin as the standard because the measurement with Lowry method was significantly affected by sulfide concentration. The effect of presence of sulfide on these analyses was carefully tested using $200 \mathrm{mg}-\mathrm{S} / \mathrm{L}$ and $500 \mathrm{mg}-\mathrm{S} / \mathrm{L} \mathrm{Na} \mathrm{Na}_{2} \mathrm{~S}$ solution, and $\mathrm{pH}$ adjustment by $\mathrm{HCl}$ and dilution was properly performed before the EPS analysis to avoid interfering. Trace metal concentrations were determined by inductively coupled plasma atomic emission spectrometer (61E-Trace, Thermo Jarrell Ash/Baird, Franklin, MA, USA). The measurements were performed via a fundamental measurement service of National Institute for Environmental Studies. Granule size distribution was determined according to the image analysis method [27] using more than 800 particles of over $0.1 \mathrm{~mm}$ in diameter. Samples during the continuous experiment were taken from port 5 (39 $\mathrm{cm}$ in height from the bottom) of the reactor. The sludge sample was spread on a petri dish and then photographed with a digital camera. The granular sludge size in both the major and minor axes was determined by an image analyzer (Image J, National Institutes of Health, Bethesda, MD, USA), and the diameter was calculated based on major axes. Median diameter d50 was calculated according to particle size distribution data expressed as cumulative frequency (\%) against particle size $(\mathrm{mm})$. The estimation of the form of metal based on an equilibrium speciation model was performed by Visual MINTEQ [28].

\section{Results and Discussion}

3.1. Extracellular Polymeric Substance (EPS) Elution and Granule Disintegration in the Presence of High-Concentration Sulfur Compounds

Dissolution experiments were performed to examine whether or not the presence of reduced sulfur compounds (sulfide, methanethiol, DMS, DMDS) makes an elution of EPS from the granules. First of all, the EPS extracted from the granule using CER method was as follows: protein $13.2 \pm 2.5 \mathrm{mg} / \mathrm{g}$-SS, and carbohydrate $42.8 \pm 3.6 \mathrm{mg} / \mathrm{g}$-SS. These values were at similar levels to those of anaerobic 
granules obtained by other researchers [29]. Figure 2 summarizes the protein and carbohydrate released from the granules after $3 \mathrm{~h}$ shaking at $35^{\circ} \mathrm{C}$. From these results, it was found that DMS and DMDS, which did not form a precipitate, had no significant effect on the elution of EPS regardless of the concentration. On the contrary, Figure 2 clearly indicates that sulfide and methanethiol, which are relatively easy to dissolve in water and to make metal salts, caused an elution of EPS protein and carbohydrate. The amount of EPS dissolution increased with concentrations of sulfide and methanethiol in the range of $0 \mathrm{mg}-\mathrm{S} / \mathrm{L}$ to $700 \mathrm{mg}-\mathrm{S} / \mathrm{L}$. Sulfide had the most powerful influence in dissolution of EPS among the four sulfur compounds investigated.
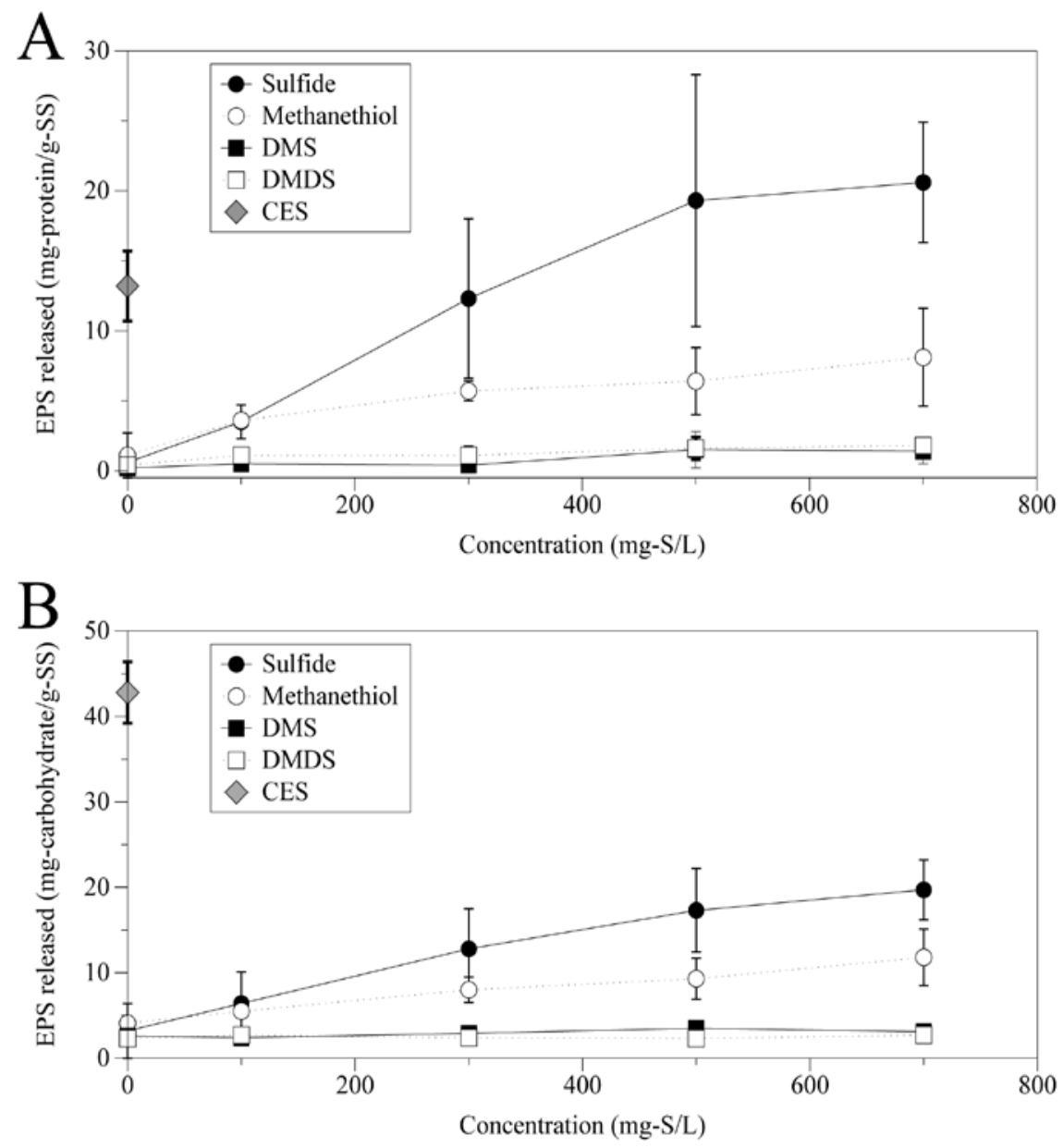

Figure 2. Protein (A) and carbohydrate (B) released from the granules at different concentrations of sulfur compounds.

The trace metal concentrations of the fresh granules taken from the full-scale plant were as follows (mg/g-dry wt.): Al $0.64 \pm$ 0.09; Ca $5.67 \pm$ 1.02; Co $0.04 \pm 0.01$; Cu $0.05 \pm 0.01$; Fe $12.7 \pm 1.6$; Mg $1.32 \pm 0.27$; Mn $0.09 \pm 0.01$; Ni $0.05 \pm 0.01$; Zn $0.17 \pm 0.02$; and Mo $0.04 \pm 0.00$. The composition of trace metals in the anaerobic granules widely varied depending on wastewater types [30]. In this study, measurement results clearly suggest that Fe and Ca were the main trace element and they seemed to play important roles in the biofilm structure forming cation-EPS bounds. EPS integrates microbial flocs in a three-dimensional matrix due to bindings with bivalent cations and hydrophobic interactions [31]. To destroy the matrix and elute EPS in water, therefore, the extraction method using CER depends on chemical removal of divalent cations such as $\mathrm{Ca}^{2+}$ binding with EPS [31]. In a similar way, the sulfide 
and methanethiol were likely to play an important role in removal of metal cations such as $\mathrm{Fe}^{2+}$ from the liquid phase and granules by forming insoluble iron salts. After the experiment using sulfide (0-700 mg-S/L), for each granule sample, only particles greater than $0.5 \mathrm{~mm}$ to remove FeS precipitate were carefully washed with water, and exchangeable cations were extracted with $1 \mathrm{M}$ ammonium acetate. Figure 3 shows a relationship between extracted $\mathrm{Fe}^{2+}$ ion and EPS released. Part of the $\mathrm{Fe}^{2+}$ ion seems to be responsible for cation-EPS-cell matrix. This figure clearly suggests that there is a negative correlation between the absorbed $\mathrm{Fe}^{2+}$ and $\mathrm{EPS}$ release. Thus, the more $\mathrm{Fe}^{2+}$ is removed from the granules, the more EPS is released. This result supports the discussions above. It should be noted that the EPS protein concentration obtained at $700 \mathrm{mg}-\mathrm{S} / \mathrm{L}$ sulfide was $20.6 \mathrm{mg} / \mathrm{g}-\mathrm{SS} \pm 4.3 \mathrm{mg} / \mathrm{g}-\mathrm{SS}$, which was 1.6 times larger than the extracted one via the CER method in the first experiment. Such a large amount of EPS released by sulfide suggests that $\mathrm{Fe}^{2+}$ contributed much to help EPS to form the matrix structure due to the major divalent metal ion in the granule. On the other hand, the carbohydrate released with sulfide was at a lower level than that using CER. As other researchers pointed out, each extraction method might target at different types of EPS in biofilm structure. For example, CER is highly selective for $\mathrm{Ca}^{2+}$ and $\mathrm{Mg}^{2+}$-bound EPS [32], while sulfide might be for $\mathrm{Fe}^{2+}$-bound EPS. Perhaps, in this research case, $\mathrm{Ca}^{2+}$ - and $\mathrm{Mg}^{2+}$-bound EPS was rich in carbohydrate not in protein, and vice versa for $\mathrm{Fe}^{2+}$-bound EPS. From the results of dissolution experiments, it was found that a large amount of EPS could be eluted from the granules in the presence of sulfide and methanethiol.

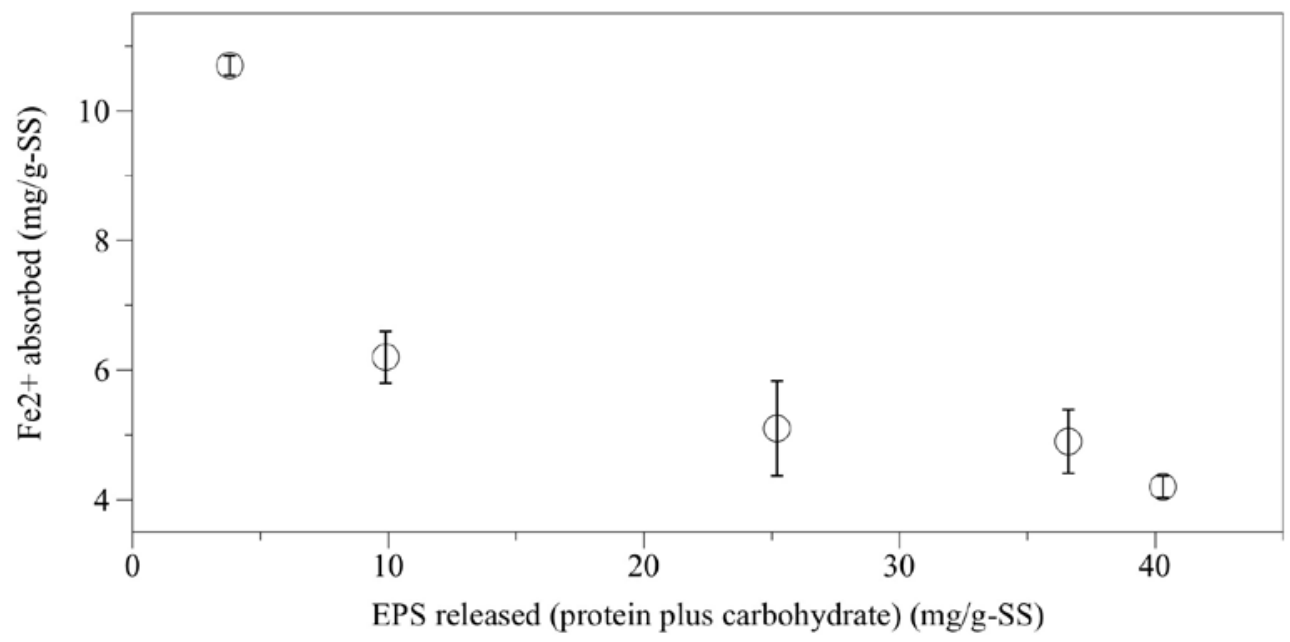

Figure 3. Relationship between $\mathrm{Fe}^{2+}$ absorbed to granules and the extracellular polymeric substance (EPS) released after the batch experiment with sulfide (0-700 mg-S/L).

Subsequently, temporal change of granule size distribution in the presence of a high concentration of sulfide, which had the strongest influence in EPS elution, was monitored. Figure 4 shows the time courses of EPS protein released from granules (Figure 4A), turbidity (Figure 4B) and median diameter d50 (Figure 4C) within the particle distributions of sludge $(>0.1 \mathrm{~mm}$ ) at sulfide concentrations of 0, 200, $500 \mathrm{mg}-\mathrm{S} / \mathrm{L}$. Turbidity is a common parameter showing amount of granule break-up [33,34]. During eight hours shaking at $35{ }^{\circ} \mathrm{C}$, it was clearly indicated that increase in EPS release, turbidity and decrease in d50 occurred. The rapid release of EPS protein was observed: the release of EPS protein was saturated within the first $2 \mathrm{~h}$ at $500 \mathrm{mg}-\mathrm{S} / \mathrm{L}$ while granules at $0 \mathrm{mg}-\mathrm{S} / \mathrm{L}$ and $200 \mathrm{mg}-\mathrm{S} / \mathrm{L}$ showed slight increase with time. Even after 8 h, the amount of EPS protein released without sulfide addition 
was only $7 \%$ of that at $500 \mathrm{mg}-\mathrm{S} / \mathrm{L}$. This implies the presence of sulfide had a much greater impact on EPS elution than the mechanical shear stress. Many different kinds of physical and chemical methods for EPS extraction have been investigated [29,30]. D’Abzac et al. [30] reported that physical methods including centrifugation, sonication and heating had less extraction yield than chemical methods including formaldehyde, $\mathrm{NaOH}$, ethanol and ethylenediaminetetraacetic acid (EDTA).
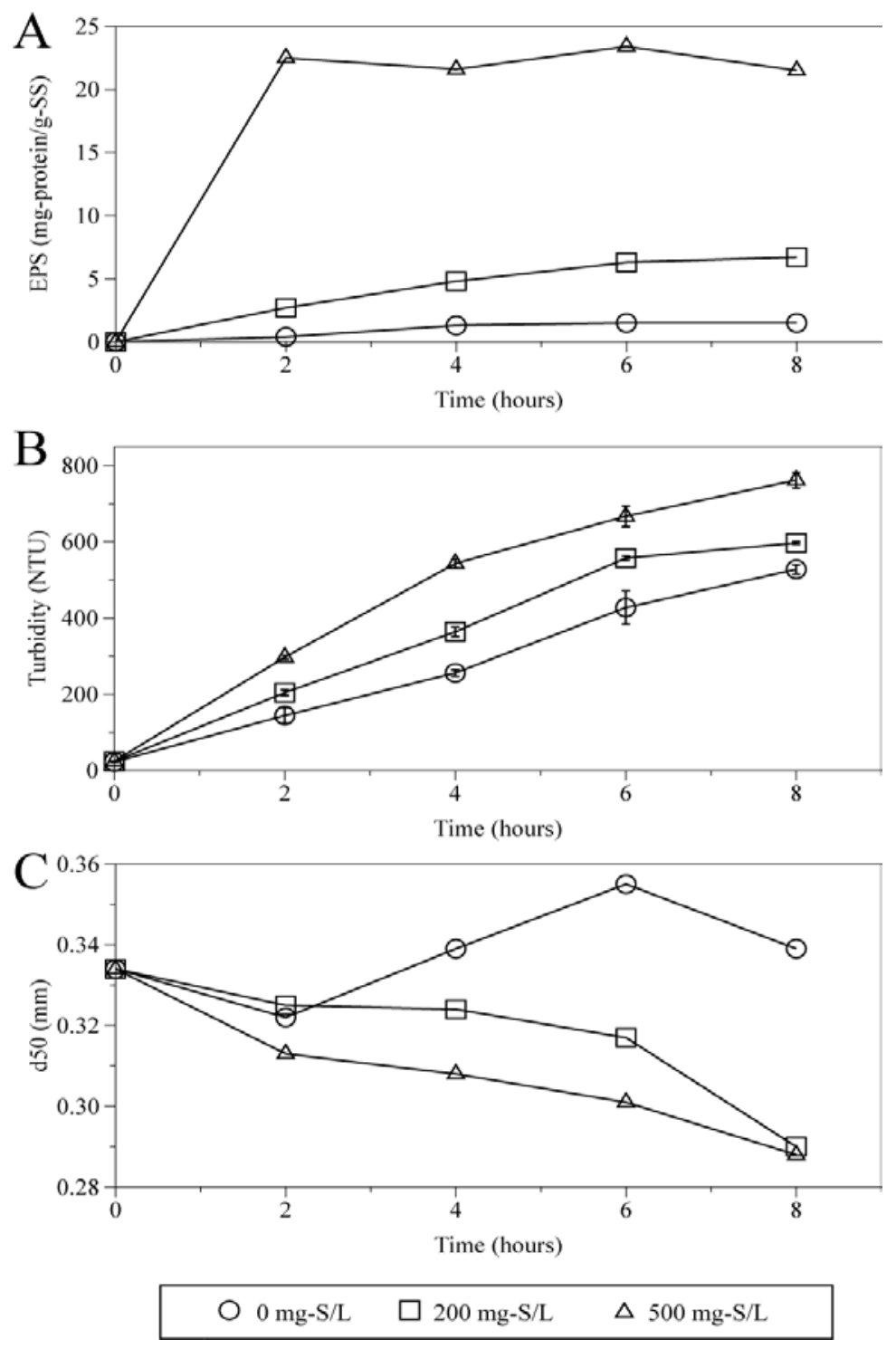

Figure 4. Time course of EPS protein released from the granules (A), turbidity (B) and median diameter of particles $(>0.1 \mathrm{~mm})(\mathbf{C})$ at different concentrations of sulfide.

For example, EPS obtained in sonication treatments was only $7 \%-30 \%$ of that in EDTA treatment [30]. However, the fact remains that sonication induces considerable break-up of granules [33,34]. This means that destruction of granules does not always depend on absence of EPS. Nevertheless, a combination of physical stress and EPS release is likely to promote granule destruction. As time went on, the contents of the bottle with higher sulfide concentration became turbid and scattered earlier. The increasing rate of turbidity was clearly dependent on sulfide concentration. For example, the increase in turbidity reached similar levels around $600 \mathrm{NTU}$ within 4, 6, $8 \mathrm{~h}(0 \mathrm{mg}-\mathrm{S} / \mathrm{L})$. However, the fact that all the samples showed significant increase in turbidity suggested that the increase partially depended 
on shear force caused by the shaking. It has been known that shear force causes cell erosion and deflocculation of anaerobic flocs, and consequently increases dispersed particles in solution [35]. Thus, that kind of dispersed particles contributed to increasing turbidity. Sheng et al. [35] suggested that even small amount of EPS (10-15 mg/g-SS) glued most of the dispersed particles and had a significant effect on the floc stability against shear stress, and furthermore, they proposed a multi-layer structural model, in which sludge flocs consists of stability part and dispersible part. The outer region of flocs is the dispersible part, which is loosely glued by EPS and can be eluted by shear force. By contrast, the stability part is so tight that it cannot be dispersed by shear under normal conditions. As such, EPS elusion caused by the presence of sulfide is thought to accelerate dispersion of so-called dispersible part of the granules. From the results obtained, it can be concluded that exposure to very high concentration of sulfide negatively affected the EPS-related complex matrix and promoted the dispersion of the small particles.

Figure 4C indicates that there was apparent difference in median diameters between granules with and without sulfide. While the $\mathrm{d} 50$ maintained above $3.2 \mathrm{~mm}$ at $0 \mathrm{mg}-\mathrm{S} / \mathrm{L}$, those were gradually decreased to below $3.0 \mathrm{~mm}$ after $8 \mathrm{~h}$ in the presence of $200 \mathrm{mg}-\mathrm{S} / \mathrm{L}$ and $500 \mathrm{mg}-\mathrm{S} / \mathrm{L}$ sulfide. Although there was little difference in d50 between the conditions of $200 \mathrm{mg}-\mathrm{S} / \mathrm{L}$ and $500 \mathrm{mg}-\mathrm{S} / \mathrm{L}$, the size distribution appeared rather different. Figure 5 shows the size distribution of granules at each sulfide concentration after $8 \mathrm{~h}$. The distributions of three samples clearly consisted of smaller particles than that of raw granule sample. Approximately $30 \%$ of the raw granules were within the range of $0.5-3 \mathrm{~mm}$. The cumulative frequency curves represent very small fraction less than $0.15 \mathrm{~mm}$ in diameter occupied the large part $(14 \%)$ of the granules at $500 \mathrm{mg}-\mathrm{S} / \mathrm{L}$ unlike other conditions. Although similar distributions were observed in the range of $0.10 \mathrm{~mm}$ to $0.25 \mathrm{~mm}$ between $0 \mathrm{mg}-\mathrm{S} / \mathrm{L}$ and $200 \mathrm{mg}-\mathrm{S} / \mathrm{L}$ conditions, there were more large granules at $0 \mathrm{mg}-\mathrm{S} / \mathrm{L}$. Granules of above $0.5 \mathrm{~mm}$ in diameter accounted for approximately 20\% (0 mg-S/L) and 12\% (200 mg-S/L), respectively.

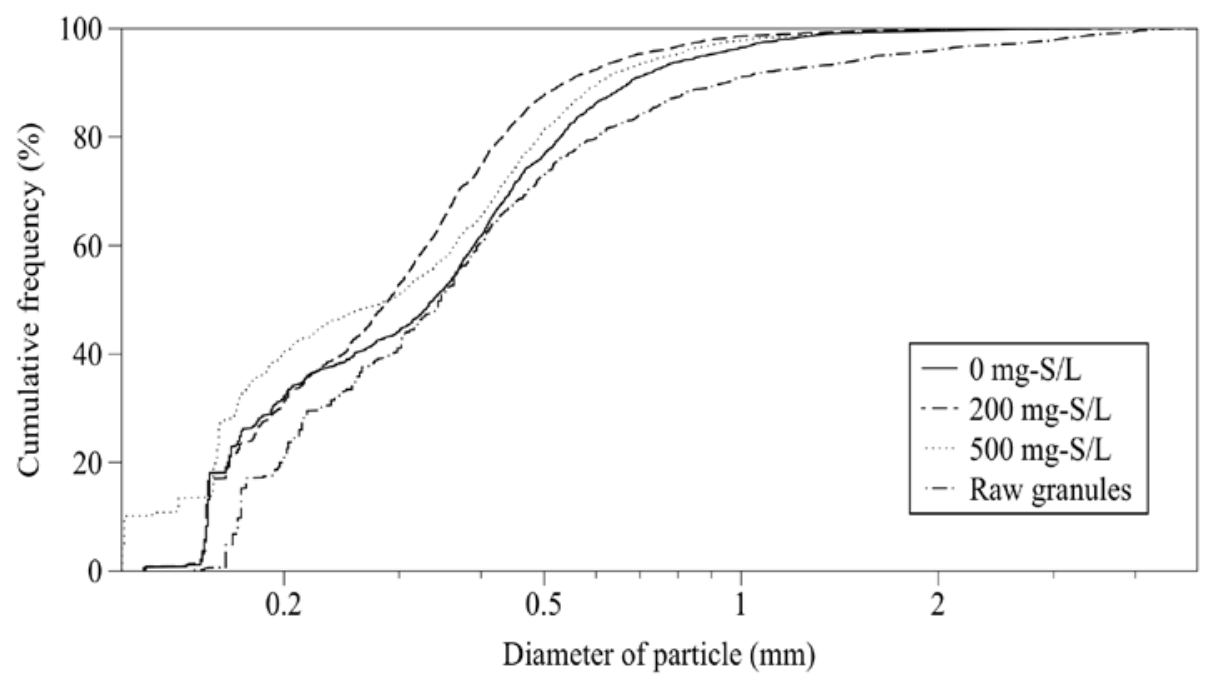

Figure 5. Size distributions of the particles $(>0.1 \mathrm{~mm})$ after $8 \mathrm{~h}$ of the experiment at different concentrations of sulfide.

These results pointed out the possibility that the presence of sulfide promoted decline in size of granules during the experiment, which was likely due to decrease in strength caused by EPS elution, 
leading to disintegration of granules. There has been a report that decrease in EPS content led to the strength of granules [16]. Ismail et al. [16] suggested that a high concentration of sodium ion (20 g/L) caused EPS release from the granule, and this led to decrease in strength. The mechanism of EPS release of their works was similar to our findings: cation exchange driven by the high concentrations of $\mathrm{Na}^{+}$removed $\mathrm{Ca}^{2+}$ bound to EPS and loosened the binding of EPS. Moreover, it was thought that the displacement of $\mathrm{Ca}^{2+}$ from the EPS resulted in a swollen granule structure due to repulsive electrostatic forces, which might be why granule size increased after long-term exposure to high salinity. In this respect, there was a little difference between our findings and the previous report on exposure of high salinity because decrease in size was predominant in the presence of sulfide. On the other hand, Grotenhuis et al. [36] reported that calcium removal by addition of the calcium-specific chelant EGTA provided EPS release and decrease in median diameter of the anaerobic granules. Bruus et al. [37] also pointed out that $\mathrm{Ca}^{2+}$ extraction from activated sludge resulted in an increase in the number of small particles, turbidity and subsequently an increase in the specific resistance to filtration. The finding of this study is consistent with Grotenhuis and Bruus's works. Probably, the difference depends on the granule properties since granules developed by feeding of methanol-based wastewater consists of coccus-shaped cells [38], while the granules used by Ismail et al. [16] consist of complicatedly entangled filamentous cells. A filamentous cell-based granule seems to maintain the adhered structure without cohesion of EPS. Since the substrate Ismail et al. [16] used involved acetate, gelatin and starch, microbial community structure was different between this study and theirs, and it was likely to affect granule structure.

\subsection{Effect of High Concentration of Sulfide on Performance of Up-Flow Anaerobic Sludge Blanket (UASB) Process in a Continuous Experiment}

The continuous operation using three UASB reactors fed with different concentrations of sulfide (10, 200, $500 \mathrm{mg}-\mathrm{S} / \mathrm{L})$ was investigated for about 90 days to clarify the effect of the presence of high concentration sulfide on operation performance and sludge retention. Figure 6 illustrates the time course of methane production rate, SS concentration and soluble protein in the effluent. During the experiment, entire three reactors operated successfully with a suitable $\mathrm{pH}$ range (7.4-7.8) and no volatile fatty acid detected. However, compared to the lower sulfide conditions (10 mg-S/L, $200 \mathrm{mg}-\mathrm{S} / \mathrm{L}$ ), the reactor at $500 \mathrm{mg}-\mathrm{S} / \mathrm{L}$ showed around $5 \%-10 \%$ lower methane production rate. The gas production rate was gradually increased with shortening HRT from four-day $\left(2.5 \mathrm{~kg}-\mathrm{COD} / \mathrm{m}^{3} / \mathrm{d}\right.$ of organic loading rate (OLR)) to one-day (10 kg-COD/m³/d of OLR) loading rate. The composition of biogas was within the range from $70 \%-80 \%$ methane, $19 \%-27 \% \mathrm{CO}_{2}, 0.1 \%-4 \% \mathrm{~N}_{2}$ in each reactor. There was a large variation in $\mathrm{H}_{2} \mathrm{~S}$ concentration in the biogas: 3-100 ppm (10 mg-S/L); 700-5000 ppm (200 mg-S/L); and 10,000-20,000 ppm (500 mg-S/L). The average methane production rates at a HRT of one day were $3.4 \pm 0.2$, $3.5 \pm 0.1,3.0 \pm 0.4 \mathrm{~L} / \mathrm{L}$-reactor/d, respectively. The COD removal efficiency showed a slight decrease with increase in sulfide fed: the COD concentrations in the effluent were $396 \pm 227,550 \pm 324$, $946 \pm 747 \mathrm{mg} / \mathrm{L}$ and the removal efficiencies were $96.9 \% \pm 1.0 \%, 94.4 \% \pm 3.3 \%, 90.9 \% \pm 7.3 \%$. To understand specific methanogenic activity per unit volume of microorganisms, batch activity tests were conducted during continuous operation at a HRT of one day. The activities of the reactor sludges were as follows: $23.5 \pm 13.7,19.3 \pm 4.6,11.5 \pm 1.1 \mathrm{~mL} / \mathrm{h} / \mathrm{g}-\mathrm{VSS}(500 \mathrm{mg}-\mathrm{S} / \mathrm{L})$. 


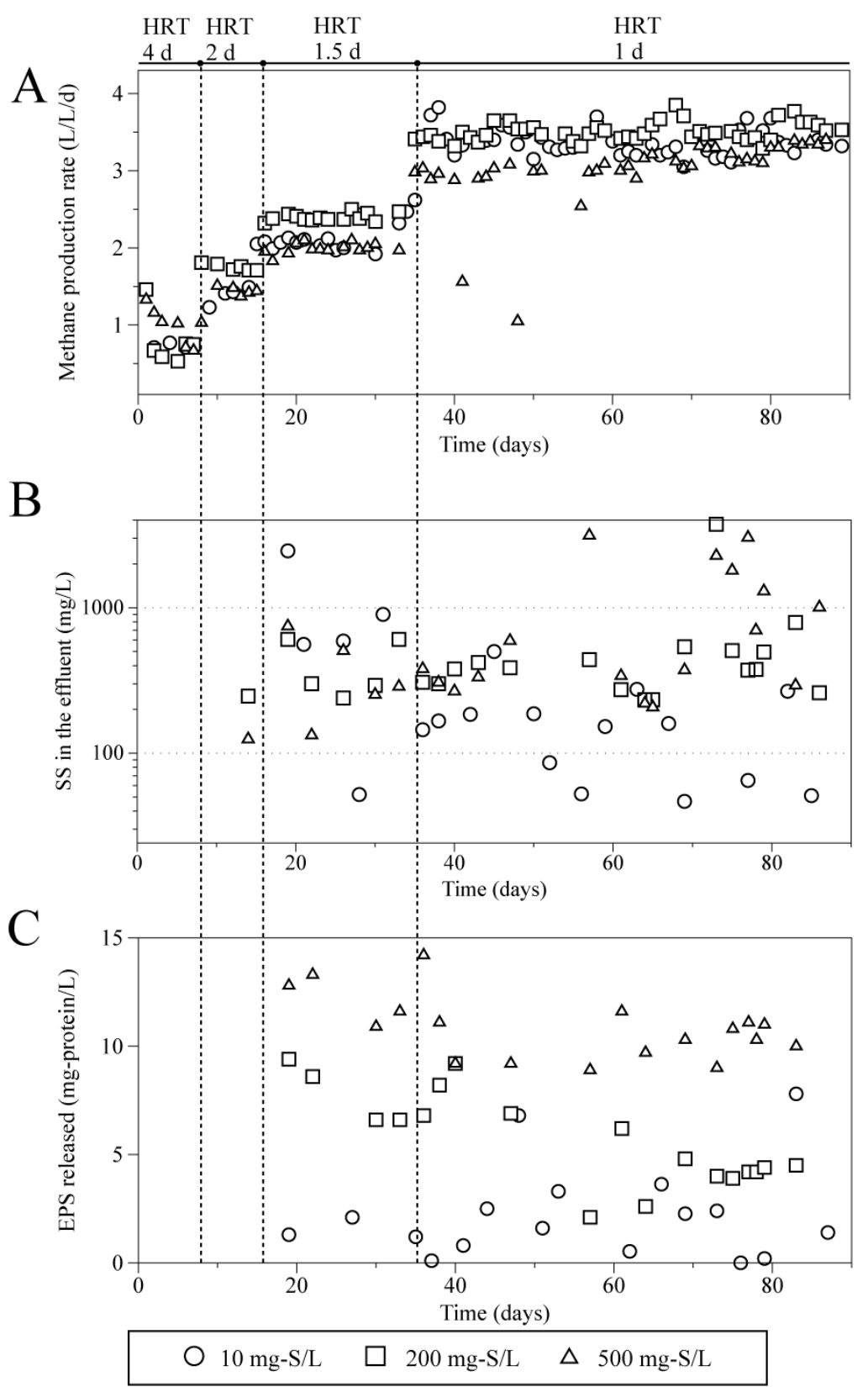

Figure 6. Performance evolutions during the continuous operation of up-flow anaerobic sludge blanket (UASB) reactors at different concentrations of sulfide in the influent wastewater: methane production rate from a unit volume of reactor (A), suspended solids (SS) concentration in the effluent (B), and EPS protein in the effluent (C).

As the results show, the microorganisms in the control reactor had the highest activity and those in the highly sulfide-fed reactor were considerably inhibited. Visser et al. [39] reported that 50\% inhibition in methanogenic activity of granular sludge occurred around $300 \mathrm{mg} / \mathrm{L}$ total sulfide concentration at $\mathrm{pH} 7.1-7.3$ and $400 \mathrm{mg} / \mathrm{L}$ at 8.1-8.3. At $500 \mathrm{mg}-\mathrm{S} / \mathrm{L}$ condition, the total sulfide concentration except $\mathrm{H}_{2} \mathrm{~S}$ gas outflowed in the liquid phase was around $300 \mathrm{mg} / \mathrm{L}$. This is within the inhibitory range described above. Our finding was consisted with the previous study. However, most studies dealt with sulfate-containing wastewater as influent, and inhibition of methanogens resulted in sharp decrease in methane content due to substrate competition between methanogens and SRB [40-42]. In the present study, the reactors maintained over $90 \%$ of methane conversion based on influent COD. 
These values were similar to the results of long-term (over one year) operation of methanol-based wastewater treatment using the similar UASB reactors and feeding, but with a little sulfur compounds, reporting more than $90 \%$ COD to methane conversion [38]. This is likely due to absence of the competition between methanogen and SRB because the reactors fed with sulfate recorded only $67 \%-70 \%$ of COD to methane conversion with the feeding of 200-333 mg-S/L sulfate [42]. There are two possible reasons for the low activity in the presence of high concentration sulfide: (1) reduction of bioavailability of metal ions precipitated as insoluble salts of Co, Ni and Fe [43]; and (2) toxicity of sulfide to microorganism [41]. The equilibrium calculation suggested that in 200 and $500 \mathrm{mg}-\mathrm{S} / \mathrm{L}$ sulfide-containing influent wastewaters, over $99.7 \%$ of $\mathrm{Fe}$, $\mathrm{Ni}$, Co were present in the forms of solid (inert sulfide salt) at $35{ }^{\circ} \mathrm{C}$ and $\mathrm{pH}$ 7.8. As such, not only toxicity but also limited metal availability could be a possible inhibitory factor in the continuous experiment. These findings presented above revealed that the operational performance was slightly negatively affected by the presence of high concentration sulfide; however, the negative impact was likely smaller than that caused in the treatment of highly sulfate-containing wastewater.

As shown in Figure 6B, highly sulfide-fed reactors (200 mg-S/L and $500 \mathrm{mg}-\mathrm{S} / \mathrm{L}$ ) showed higher levels of SS concentration in the effluent during the experiments. The effluent of the two reactors contained a lot of small black particles while that of control reactor with $0 \mathrm{mg}-\mathrm{S} / \mathrm{L}$ feeding was relatively clear and only a few particles were observed. Since large granules sometimes floated up and flowed out from the reactor, the sulfide-fed reactors showed sharp increases in SS to over $1 \mathrm{~g} / \mathrm{L}$ in the effluent. The average SS concentrations in the effluent were $245 \pm 146,592 \pm 826$, and $976 \pm 993 \mathrm{mg} / \mathrm{L}$, respectively. This indicates the outflow of sludge increased according to sulfide concentration in the influent. Figure 7 indicates the mixed liquor volatile suspended solids (MLVSS) concentration in the reactors (Figure 7A) and the median diameter of the granules taken from the middle part of each reactor (port 5). MLVSS concentrations were average values calculated using those of sludge obtained from the eight sampling ports. Figure 7A shows that there was a clear difference between the reactors with and without high concentration sulfide. The height of sludge bed of the reactors with 200 and 500 mg-S/L sulfide-feeding decreased during the 90 days of operation. The height of sludge bed was around $50 \mathrm{~cm}$ initially. However, the MLVSS concentrations mainly in the upper part were decreased with time in the presence of high concentration of sulfide. The MLVSS from ports 1 to 4 (above $48 \mathrm{~cm}$ from the bottom) were within 7.9-32 g/L at the beginning, and those after 90 days were 40-63, 3.3-7.3, and 2.1-2.9 g/L (500 mg-S/L), respectively. This is likely due to the outflow of sludge, as suggested in the effluent SS (Figure 6B). Moreover, Figure 7B indicates decrease in diameter of the granules inside the reactors. This is likely one of the reasons for flotation and washout of sludge from the reactor, resulting in the reduced sludge concentration. It was also noted that despite of seeding relatively larger granule selectively, all the reactors including the control ones showed significant decrease in median diameter of granules. As the previous study suggested [38], a continuous treatment of methanol-based wastewater reduces granule sizes. For this reason, in this case, the reduction in granule sizes would depend on not only high concentration sulfide, but also substrate type. Even so, the data implies high concentration sulfide contributed more to the decrease in granule sizes. 

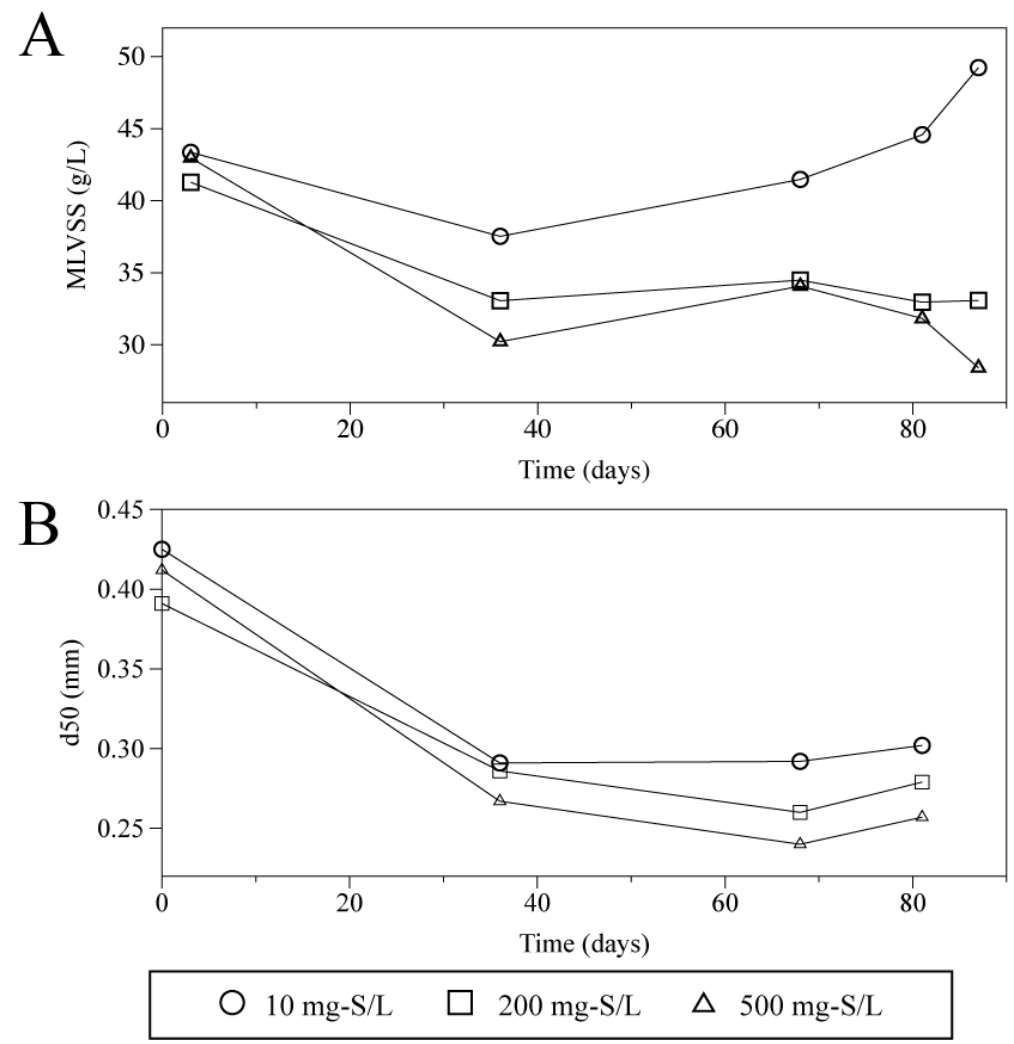

Figure 7. Time courses of the mixed liquor volatile suspended solids (MLVSS) of sludge in UASB reactors (A) and median diameter of the particles obtained from the middle part of the UASB reactor $(\mathbf{B})$.

The increase in soluble protein concentration in the effluent observed in highly sulfide-fed reactors pointed out the possibility that high concentration sulfide eluted EPS and destroy granules in the similar way to the batch experiments described above. Figure 6C clearly illustrates that the two reactors showed rather higher ranges of protein $(8.9-14.2 \mathrm{mg} / \mathrm{L}$ at $500 \mathrm{mg}-\mathrm{S} / \mathrm{L} ; 2.1-9.4 \mathrm{mg} / \mathrm{L}$ at $200 \mathrm{mg}-\mathrm{S} / \mathrm{L}$ ) than the control reactor; however, slight decreases were observed during the latter part of the operation duration. The average soluble protein concentrations of each reactor were $2.2 \pm 1.9,5.1 \pm 2.0$, and $10.5 \pm 1.4 \mathrm{mg} / \mathrm{L}$, respectively, showing a gradual increase in accordance with the sulfide concentration. These are similar results obtained from the dissolution experiments. The cumulative soluble protein flowed out from the reactor was calculated using the average concentration. The cumulative sum was at most $3.1 \mathrm{~g}$ during the 90 days operation at $500 \mathrm{mg}-\mathrm{S} / \mathrm{L}$. This could be expressed as $14.8 \mathrm{mg}$ per g-SS of seeded granules. The value was less than that obtained from the dissolution experiment for only $3 \mathrm{~h}$. From this estimation, it was found that the release of EPS from a UASB reactor in continuous operation seemed to be very slow. Jeison et al. [44] and Ismail et al. [16] also noticed the change in EPS content and granule size distribution as a result of high saline conditions after long-term continuous operations over 150 days. The difference in duration required to release EPS between the batch and continuous experiments is likely due to the effect of shear force. As discussed above, shear force is a major factor dispersing small particles and EPS gluing them [35]. The continuous experiment in this study had the lower up-flow liquid velocity (below $0.1 \mathrm{~m} / \mathrm{h}$ ) than those of full-scale UASB plants (around $1 \mathrm{~m} / \mathrm{h}$ ), creating a weaker shear force than that of the batch test with a mechanical shaking. On the other hand, the too low up-flow liquid velocity of laboratory 
reactor might negatively affect granule stability since the importance of moderate hydrodynamic shear force caused by up-flow velocity in the granule stability has been pointed out, while the granule structure tends to become a heterogeneous, porous and weaker structure when the shear force is too weak [45]. In addition, the actual sulfide concentration in the UASB reactor was lower than the bottles used for dissolution experiments. In the UASB reactor, about 30\% (200 mg-S/L) and 60\% (500 mg-S/L) of the influent sulfide was outflowed as $\mathrm{H}_{2} \mathrm{~S}$ gas based on average biogas production and $\mathrm{H}_{2} \mathrm{~S}$ concentrations, and therefore, the sulfide was actually reduced. As mentioned above, most Fe was likely to be in the form of $\mathrm{FeS}$ solids in the reactor, and $\mathrm{Fe}^{2+}$ responsible for good granulation. Actually, the $\mathrm{Fe}^{2+}$ concentration was always below $0.2 \mathrm{mg} / \mathrm{L}$ in the two reactors $(200 \mathrm{mg}-\mathrm{S} / \mathrm{L}$ and $500 \mathrm{mg}-\mathrm{S} / \mathrm{L}$ ) while that was $1-9 \mathrm{mg} / \mathrm{L}$ in the control reactor. In the work of Liu et al. [46], enhancement in granulation was observed at a $\mathrm{Fe}^{2+}$ level around $60 \mathrm{mg} / \mathrm{L}$. Compered to the proper level, $\mathrm{Fe}^{2+}$ concentrations in this study were very low. Moreover, $\mathrm{Mg}, \mathrm{Ca}$, and $\mathrm{Al}$, which help granulation, were at rather lower level in the influent than the optimal levels (300-700 mg/L) [21,23,24]. As such, metal supply was severely limited in the reactors of the present study in terms of not only microbial nutrients but also granulation. Since there was a report that $\mathrm{Ca}^{2+}$ addition stabilized granules owing to EPS elution [16], metal supplementation might reduce EPS release and enhance granules retention. Further research is needed to stabilize granule in the system investigated in this study.

\section{Conclusions}

The effect of exposure to high concentrations of reduced sulfur compounds on the granular sludge was investigated. Batch experiments revealed that considerable amount of EPS was eluted in the presence of sulfide and methanethiol according to their concentrations. In addition, the presence of sulfide reduced the strength of granules and accelerated decrease in granule size by shearing force. The continuous experiments of UASB reactors demonstrated that the high concentration of sulfide fed reactors allowed outflow of EPS protein and more washout of granular sludge. Finally, the presence of sulfide negatively affected methane production, COD removal and sludge retention.

\section{Acknowledgments}

The authors thank Daichi Yanagida for help with operation of the UASB reactors.

\section{Author Contributions}

Takuro Kobayashi played a main role in design of the research, experiment and writing the manuscript. Kai-Qin Xu contributed to editing the manuscript and discussion. Haruyuki Chiku took samples from the full-scale plant and characterized granules.

\section{Conflicts of Interest}

The authors declare no conflict of interest. 


\section{References}

1. Latif, M.A.; Ghufran, R.; Wahid, Z.A.; Ahmad, A. Integrated application of upflow anaerobic sludge blanket reactor for the treatment of wastewaters. Water Res. 2011, 45, 4683-4699.

2. Veeresh, G.S.; Kumar, P.; Mehrotra, I. Treatment of phenol and cresols in upflow anaerobic sludge blanket (UASB) process: A review. Water Res. 2005, 39, 154-170.

3. Guiot, S.R.; Pauss, A.; Costerton, J.W. A structured model of the anaerobic granule consortium. Water Sci. Technol. 1992, 25, 1-10.

4. Tiwari, M.K.; Guha, S.; Harendranath, C.S.; Tripathi, S. Influence of extrinsic factors on granulation in UASB reactor. Appl. Microbiol. Biotechnol. 2006, 71, 145-154.

5. Gonzalez, J.S.; Rivera, A.; Borja, R.; Sanchez, E. Influence of organic volumetric loading rate, nutrient balance and alkalinity: COD ratio on the anaerobic sludge granulation of an UASB reactor treating sugar cane molasses. Int. Biodeterior. Biodegrad. 1998, 41, 127-131.

6. Singh, R.P.; Kumar, S.; Ojha, C.S.P. Nutrient requirement for UASB process: A review. Biochem. Eng. J. 1999, 3, 35-54.

7. Singh, K.S.; Viraraghavan, T. Impact of temperature on performance, microbiological, and hydrodynamic aspects of UASB reactors treating municipal wastewater. Water Sci. Technol. 2003, 48, 211-217.

8. Fang, H.H.; Chen, T.; Li, Y.Y.; Chui, H.K. Degradation of phenol in wastewater in an upflow anaerobic sludge blanket reactor. Water Res. 1996, 30, 1353-1360.

9. Erguder, T.H.; Guven, E.; Demirer, G.N. The inhibitory effects of lindane in batch and upflow anaerobic sludge blanket reactors. Chemosphere 2003, 50, 165-169.

10. Morgan, J.W.; Forster, C.F.; Evison, L.M. A comparative study of the nature of biopolymers extracted from anaerobic and activated sludge. Water Res. 1990, 24, 743-750.

11. Jia, X.S.; Fang, H.H.; Furumai, H. Surface charge and extracellular polymer of sludge in the anaerobic degradation process. Water Sci. Technol. 1996, 34, 309-316.

12. Boari, G.; Brunetti, A.; Passino, R.; Rozzi, A. Anaerobic digestion of olive oil mill wastewaters. Agric. Wastes 1984, 10, 161-175.

13. Petruy, R.; Lettinga, G. Digestion of a milk-fat emulsion. Bioresour. Technol. 1997, 61, 144-149.

14. Chou, H.H.; Huang, J.S. Comparative granule characteristics and biokinetics of sucrose-fed and phenol-fed UASB reactors. Chemosphere 2005, 59, 107-116.

15. Borzacconi, L.; López, I.; Passeggi, M.; Etchebehere, C.; Barcia, R. Sludge deterioration in a full scale UASB reactor after a pH drop working under low loading conditions. Water Sci. Technol. 2008, 57, 797-802.

16. Ismail, S.B.; de La Parra, C.J.; Temmink, H.; Van Lier, J.B. Extracellular polymeric substances (EPS) in upflow anaerobic sludge blanket (UASB) reactors operated under high salinity conditions. Water Res. 2010, 44, 1909-1917.

17. Weijma, J.; Stams, A.J.; Hulshoff Pol, L.W.; Lettinga, G. Thermophilic sulfate reduction and methanogenesis with methanol in a high rate anaerobic reactor. Biotechnol. Bioeng. 2000, 67, 354-363.

18. Goorissen, H.P.; Stams, A.J.; Hansen, T.A. Methanol utilization in defined mixed cultures of thermophilic anaerobes in the presence of sulfate. FEMS Microbiol. Ecol. 2004, 49, 489-494. 
19. O’Reilly, C.; Colleran, E. Effect of influent $\mathrm{COD} / \mathrm{SO}_{4}{ }^{2-}$ ratios on mesophilic anaerobic reactor biomass populations: Physico-chemical and microbiological properties. FEMS Microbiol. Ecol. 2006, 56, 141-153.

20. Fermoso, F.G.; Bartacek, J.; Jansen, S.; Lens, P.N. Metal supplementation to UASB bioreactors: From cell-metal interactions to full-scale application. Sci. Total Environ. 2009, 407, 3652-3667.

21. Schmidt, J.E.; Ahring, B.K. Effect of magnesium on thermophilic acetate-degrading granules in upflow anaerobic sludge blanket (UASB) reactors. Enzym. Microb. Technol. 1993, 15, 304-310.

22. Yu, H.Q.; Fang, H.H.P.; Tay, J.H. Effects of $\mathrm{Fe}^{2+}$ on sludge granulation in upflow anaerobic sludge blanket reactors. Water Sci. Technol. 2000, 41, 199-205.

23. Yu, H.Q.; Fang, H.H.P.; Tay, J.H. Enhanced sludge granulation in upflow anaerobic sludge blanket (UASB) reactors by aluminium chloride. Chemosphere 2001, 44, 31-36.

24. Yu, H.Q.; Tay, J.H.; Fang, H.H. The roles of calcium in sludge granulation during UASB reactor start-up. Water Res. 2001, 35, 1052-1060.

25. Speece, R.E. Anaerobic biotechnology for industrial wastewater, Environ. Sci. Technol. 1983, 17, 416-427.

26. JSWA Examination Method for Wastewater and Sludge; Japan Sewage Works Association: Tokyo, Japan, 1997.

27. Yoochatchaval, W.; Tsushima, I.; Yamaguchi, T.; Araki, N.; Sumino, H.; Ohashi, A.; Harada, H.; Syutsubo, K. Influence of sugar content of wastewater on the microbial characteristics of granular sludge developed at $20{ }^{\circ} \mathrm{C}$ in the anaerobic granular sludge bed reactor. J. Environ. Sci. Health A Toxic Hazard. Subst. Environ. Eng. 2009, 44, 921-927.

28. Gustafsson, J.P. Visual MINTEQ (v3.0). A Windows version of MINTEQA2. Available online: http://vminteq.lwr.kth.se (accessed on 1 March 2015).

29. Liu, H.; Fang, H.H. Extraction of extracellular polymeric substances (EPS) of sludges. J. Biotechnol. 2002, 95, 249-256.

30. D’Abzac, P.; Bordas, F.; Van Hullebusch, E.; Lens, P.N.; Guibaud, G. Extraction of extracellular polymeric substances (EPS) from anaerobic granular sludges: Comparison of chemical and physical extraction protocols. Appl. Microbiol. Biotechnol. 2010, 85, 1589-1599.

31. Frolund, B.; Palmgren, R.; Keiding, K.; Nielsen, P.H. Extraction of extracellular polymers from activated sludge using a cation exchange resin. Water Res. 1996, 30, 1749-1758.

32. Park, C.; Novak, J.T. Characterization of activated sludge exocellular polymers using several cation-associated extraction methods. Water Res. 2007, 41, 1679-1688.

33. Morgan, J.W.; Forster, C.F. A comparative study of the sonication of anaerobic and activated sludges. J. Chem. Technol. Biotechnol. 1992, 55, 53-58.

34. Forster, C.F.; Quarmby, J. The physical characteristics of anaerobic granular sludges in relation to their internal architecture. Antonie Leeuwenhoek 1995, 67, 103-110.

35. Sheng, G.P.; Yu, H.Q.; Li, X.Y. Stability of sludge flocs under shear conditions: Roles of extracellular polymeric substances (EPS). Biotechnol. Bioeng. 2006, 93, 1095-1102.

36. Grotenhuis, J.C.T.; Van Lier, J.B.; Plugge, C.M.; Stams, A.J.M.; Zehnder, A.J.B. Effect of ethylene glycol-bis( $\beta$-aminoethyl ether)-N,N-tetraacetic acid (EGTA) on stability and activity of methanogenic granular sludge. Appl. Microbiol. Biotechnol. 1991, 36, 109-114. 
37. Bruus, J.H.; Nielsen, P.H.; Keiding, K. On the stability of activated sludge flocs with implications to dewatering. Water Res. 1992, 26, 1597-1604.

38. Kobayashi, T.; Yan, F.; Takahashi, S.; Li, Y.Y. Effect of starch addition on the biological conversion and microbial community in a methanol-fed UASB reactor during long-term continuous operation. Bioresour. Technol. 2011, 102, 7713-7719.

39. Visser, A.; Hulshoff Pol, L.W.; Lettinga, G. Competition of methanogenic and sulfidogenic bacteria. Water Sci. Technol. 1996, 33, 99-110

40. Hilton, M.G.; Archer, D.B. Anaerobic digestion of a sulfate-rich molasses wastewater: Inhibition of hydrogen sulfide production. Biotechnol. Bioeng. 1988, 31, 885-888.

41. Colleran, E.; Pender, S.; Phipott, U.; O’Flaherty, V.; Leahy, B. Full-scale and laboratory-scale anaerobic treatment of citric acid production wastewater. Biodegradation 1998, 9, 233-245.

42. Hu, Y.; Jing, Z.; Sudo, Y.; Niu, Q.; Du, J.; Wu, J.; Li, Y.Y. Effect of influent COD $/ \mathrm{SO}_{4}{ }^{2-}$ ratios on UASB treatment of a synthetic sulfate-containing wastewater. Chemosphere 2015, 130, 24-33.

43. Callander, I.J.; Barford, J.P. Precipitation, chelation, and the availability of metals as nutrients in anaerobic digestion. I. Methodology. Biotechnol. Bioeng. 1983, 25, 1947-1957.

44. Jeison, D.; Rio, A.D.; Lier, J.V. Impact of high saline wastewaters on anaerobic granular sludge functionalities. Water Sci. Technol. 2008, 57, 815-819.

45. Liu, Y.; Tay, J.H. The essential role of hydrodynamic shear force in the formation of biofilm and granular sludge. Water Res. 2002, 36, 1653-1665.

46. Liu, Y.; Zhang, Y.; Quan, X.; Chen, S.; Zhao, H. Applying an electric field in a built-in zero valent iron-Anaerobic reactor for enhancement of sludge granulation. Water Res. 2011, 45, 1258-1266.

(C) 2015 by the authors; licensee MDPI, Basel, Switzerland. This article is an open access article distributed under the terms and conditions of the Creative Commons Attribution license (http://creativecommons.org/licenses/by/4.0/). 